\title{
Simon Peter and Transformative Leadership: Leadership Insights for Today's Leaders
}

\author{
Cam Caldwell ${ }^{1}$, Mark McConkie ${ }^{2} \&$ Bryan Licona $^{3}$ \\ ${ }^{1}$ School of Business, St. Thomas University, Miami Lakes, FL., USA \\ ${ }^{2}$ School of Public Affairs, University of Colorado Colorado Springs, USA \\ ${ }^{3}$ Nova Southeastern University, Davie FL., USA \\ Correspondence: Mark McConkie, Professor, School of Public Affairs, University of Colorado Colorado Springs, \\ USA. E-mail: mmcconki@uccs.edu
}

Received: November 1, 2013

Accepted: November 26, 2013

Online Published: February 15, 2014

doi:10.5430/jms.v5n1p18

URL: http://dx.doi.org/10.5430/jms.v5n1p18

\begin{abstract}
This paper examines the Apostle Peter as a personification of the relatively new leadership model, Transformative Leadership, which focuses on the leader's role as an ethical steward who owes "covenantal duties" to those whom (s)he serves. We begin by briefly explaining this new leadership model, then explaining how Peter's leadership behavior fits the transformative leadership model with its accompanying moral and ethical obligations. Focusing on the application of the six leadership perspectives in the model, we provide twelve propositions that incorporate insights from Peter's experiences and that apply to the modern leader. The third section of this paper provides a brief summary of the contributions of this paper.
\end{abstract}

Keywords: transformative leadership, ethics, Peter, change

\section{Leadership Insights for Today's Leaders}

Over the past several decades scholars have frequently cited central characters from history (Philllips, 1993; Kennedy, 2006) and religion (Youssef, 2013; Caliguire, 2003) as exemplars of leadership behavior, often suggesting that practitioners and academicians have much to learn about leadership from these leaders' teachings and their relationships with followers. Biblical characters from the Old (Pava, 2003; Rasnake \& Shepher, 2001) and New Testaments (Ascough, \& Cotton, 2006; Clinton, 2006) have been cited as role models of leadership principles worthy of emulation in the modern organization. Among these individuals, one notable exception is Simon Peter (Peter), who has received minimal attention in the leadership literature, and yet is the apostle upon whom Jesus Christ declared that his followers would depend and who is often referred to as the head of the early church (King, 2012). Peter's near absence from the leadership and management literature is notable, given his role "as one of the central figures of the Christian religion and also, inevitably, a key figure of the entire world . . yet he remains a shadowy, legendary figure" (Grant, 1995, p. 3).

In this paper we examine Peter as a personification of the relatively new leadership model, Transformative Leadership, which focuses on the leader's role as an ethical steward who owes "covenantal duties" to those whom (s)he serves (cf. DePree, 2004, Block, 1993; Caldwell, Bischoff, \& Karri, 2002). In our paper we begin by briefly explaining this new leadership model and identifying its focus on duties owed to others. We then explain how Peter's leadership behavior fits the transformative leadership model with its accompanying moral and ethical obligations. Focusing on the application of the six leadership perspectives and the underlying moral foundations that make up transformative leadership, we provide twelve propositions that incorporate insights from Peter's experiences and that apply to the modern leader. In the third section of this paper we provide a brief summary of the contributions of this paper for practitioners and leadership scholars.

\section{Transformative Leadership and Its Moral Duties}

The obligation to achieve optimal organizational outcomes and to create wealth while honoring duties owed to stakeholders has been a fundamental principle of great leadership for millennia (Solomon, 1992; Manville \& Ober, 2003; Pava, 2003). The integration of moral and economic outcomes has increasingly been emphasized as a critical function of today's leaders (Hosmer, 2007; Pfeffer, 1998; Cameron \& Spreitzer, 2012; Paine, 2003). Ciulla, Price, and Murphy (2005) have suggested that great leaders achieve organizational success draw the best out of others by living the highest standards of moral leadership. Similarly, Harvard scholar, Lynn Paine (2003), has noted that the 
modern leader must create organization solutions that merge wealth creation with the honoring of a broad array of social and ethical duties.

It is this integration of moral excellence with the maximization of long-term wealth that is the foundation of a new model of leadership that has been labeled "transformative leadership." Caldwell and colleagues (Caldwell, Dixon, Floyd, Chaudoin, Post, and Cheokas 2012, p. 176) have defined transformative leadership as "an ethically-based leadership model that integrates a commitment to values outcomes by optimizing the long-term interests of stakeholders and society and honoring the moral duties owed by organizations to their stakeholders (Italics in the original)." Transformative leadership incorporates key ethical elements of six highly-regarded leadership perspectives in describing a model of governance that asks leaders to optimize long-term wealth creation while pursuing outcomes that also serve society and that recognize duties owed to all stakeholders (Caldwell, 2012).

Table 1, provided below, is a brief summation of the six perspectives that make up transformative leadership. In addition to briefly describing each of these perspectives, Table 1 identifies the primary moral and ethical focus from each perspective which contributes to the transformative leadership model, together with a brief description of how each perspective is applied within an organizational and interpersonal context.

Table 1. A summation of the 6 leadership perspectives in transformative leadership

\begin{tabular}{|c|c|c|}
\hline Leadership Perspective & Brief Description & $\begin{array}{l}\text { Ethical Focus in } \\
\text { Transformative } \\
\text { Leadership }\end{array}$ \\
\hline Charismatic Leadership & $\begin{array}{l}\text { The leader creates strong } \\
\text { personal relationships } \\
\text { and pursues a calling } \\
\text { that inspires others. }\end{array}$ & $\begin{array}{l}\text { The focus is } \\
\text { virtue-based in the } \\
\text { pursuit of a desired } \\
\text { end that drives all } \\
\text { actions. }\end{array}$ \\
\hline $\begin{array}{l}\text { Transformational } \\
\text { Leadership }\end{array}$ & $\begin{array}{l}\text { The leader creates } \\
\text { synergistic change to } \\
\text { transform both the } \\
\text { organization and its } \\
\text { members. }\end{array}$ & $\begin{array}{l}\text { The focus is } \\
\text { duty-based in the } \\
\text { pursuit of ends that } \\
\text { comply with } \\
\text { honorable means. }\end{array}$ \\
\hline
\end{tabular}

\begin{tabular}{ll}
\hline Level Five Leadership & The leader combines a The focus is \\
& personal humility with a teleological and \\
& passionate resolve to outcome-based in the \\
& achieve the pursuit of the best \\
& organization's purpose. possible results.
\end{tabular}

Covenantal Leadership The leader is an example The focus is on the and teacher who pursues pursuit of truth and new meaning with the creation of insight others in the search for truth. and wisdom about its application.

\section{Application}

Charismatic leaders
view the organization as the means of achieving an inspired calling and the pursuit of a noble mission.

Transformational

leaders focus on the organization's ability to adapt to change and seek to empower the organization to achieve greatness.

is Level Five leaders are driven to achieve the best possible outcomes for the organization and do so with almost fanatical commitment

Covenantal leaders view continuous learning and the pursuit of new meaning as essential for an organization to survive in a changing world.
Servant Leadership

The leader is servant first and pursues service over self-interest.
The focus is on honoring the duties owed to individuals and follows an ethic of care.
Servant leaders strive to honor duties owed to the organization and view that obligation as consistent with honoring duties owed to each individual.

\begin{tabular}{ll}
\hline Principle-Centered & The leader governs \\
Leadership & $\begin{array}{l}\text { based upon universal } \\
\text { principles in achieving } \\
\text { desired goals. }\end{array}$
\end{tabular}

The focus is on

maintaining congruence universal truths in the pursuit of excellence.

\section{Principle-centered}

leaders strive to comply with universal principles and which are fundamental to the success of every organization.

\section{organization.}

\section{Interpersonal Application}

Personal bonding and
connection creates devoted followership that willingly puts the mission of the organization first.

Helping individuals to achieve their greatness allows the organization to benefit in the long run while honoring the obligation to help others adapt to a changing world.

Recognition and credit is given to others when successes are achieved and failures are viewed as the leader's personal responsibility.

\section{Learning and applying new} truths empower each organization member and are critical to their personal growth and the benefit of all.

Individuals are each owed great obligations by the leader and by the organization, and are each valued ends rather than means to the organization's ends.

Character and competence are both critically important in the establishment of high trust relationships between leaders and followers. 
As indicated, transformative leadership integrates the leader's obligation to honor duties owed at both the organizational and individual levels. In the pursuit of the "welfare, growth, and wholeness" of individuals and the optimization of long-term wealth of organizations, transformative leaders function as ethical stewards (Caldwell, Hayes, Karri, \& Bernal, 2008, p. 153-155). Writing about this stewardship commitment, Hernandez (2012, p. 173) explained that steward leaders hold "a covenantal relationship with their organizations that represents a moral commitment" in which those involved "work toward a common goal, without taking advantage of each other." DePree (2004, Ch. 1) also described the leader's obligation in terms of this covenantal set of responsibilities to both the organization and its members to help both achieve their potential greatness.

The following paragraphs briefly describe how each of the six leadership perspectives, with their accompanying ethical and moral emphases, contribute to the transformative leadership model.

\subsection{Charismatic Leadership}

Charismatic leaders are "visionary leaders who, through a combination of personal characteristics, behaviors, and the relationships they foster with followers, motivate the latter to achieve exceptional performance directed toward the vision" (Hayibor, Agle, Sears, Sonnenfeld \& Ward, 2011, p. 239). Charismatic leaders motivate others to transcend their own self-interest to accomplish a noble outcome (Brown \& Trevino, 2006). Anding (2005) explained that charismatic leaders empower others to become passionately committed to the grand ideal which an organization pursues. Charismatic leaders often feel that they have been "called" to achieve this special purpose which is intended to profoundly benefit mankind (Lussier \& Achua, 2012, p. 363).

The ethical focus of charismatic leadership is clearly virtue-based with a teleological focus on achieving a shared vision (Hayibor, et al., 2011). This ability to inspire a shared vision is widely acknowledged to be a critical role of effective leadership (Kouzes \& Posner, 2012, Ch. 5 \& 6; Bennis \& Nanus, 2007, p. 30-31). The pursuit of this vision becomes the driving force that propels the organization to achieve a noble mission, and the relationships established create the bond that motivates, inspires, and compels followers to devote themselves to achieving that vision (Kouzes \& Posner, 2012, Ch. 4 \& 5). The organization becomes the vehicle by which a charismatic leader seeks to accomplish a noble purpose and individual members are valued as participants in achieving that outcome (Conger \& Kanungo, 1998). It is the mission or purpose that drives this leader and that represents what truly matters (Brown \& Trevino, 2006, p. 955).

\subsection{Transformational Leadership}

Transformational leaders are change agents who facilitate the ability of their organizations to maintain competitive advantage while also acknowledging the organization's responsibility to help employees to continuously improve, learn, and grow (Burns, 1978; Lussier \& Achua, 2013, p. 340-342; DuBrin, 2013, p. 83-96). Transformational leaders pursue excellence as a deontological or duty-based obligation (Caldwell, 2012) and take the position that this commitment is best achieved by creating synergistic solutions that benefit both individuals and the organization in the pursuit of greatness (Cameron, 2011).

Bass (1998) explained that transformational leadership incorporated four elements. Individualized consideration encompassed the degree to which a leader attends to individual follower's needs and supporting team members in self-development. Intellectual stimulation addressed the leader's willingness to challenge assumptions and encourage follower creativity.

Inspirational motivation involved the leader's ability to motivate followers with high standards and optimism in the pursuit of worthy goals. Idealized influence was achieved by the leader's ability to model ethical behavior in earning the respect and trust of others.

Transformational leadership incorporates these four elements to focus on changes necessary to transcend individual self-interest-- but which nonetheless create a powerful benefit for individuals. At the same time these changes achieve unprecedented organizational outcomes (Avolio, Waldman, \& Yammarino, 1991; Warrick, 2011). Pearson (2012, p. 20) noted that, although the need to constantly change is a universal leadership obligation, the demands of change have made the transforming role of the leader critically important in today's global market place. The need to address the ongoing demands of a changing world makes transformational leadership a critical part of the role of the transformative leader (Bennis \& Nanus, 2007). Achieving the changes required to create a better world are viewed by the transformative leader as a moral duty that accompanies the mantle of leadership. 


\subsection{Level 5 Leadership}

Level 5 leaders combine humility with a fierce resolve and a commitment to excellence (Collins, 2001a). The Level 5 leadership model was identified by Collins (2001b) as a critical element in determining whether organizations made the transition from being good to becoming truly great. The Level 5 leader is counterintuitive to the traditional concept of the high profile leader, but Collins (2001a) found that great organizations differentiated themselves from their competitors by being led by low-keyed, humble, and fiercely committed leaders who quickly gave credit to others for success and who devoted themselves to helping the organization to succeed.

Collins (2001b, p. 2) explained that Level 5 leaders did not pursue a self-serving agenda or present themselves as the source of their organization's accomplishments, but were understated individuals who simply sought to move their organization forward. In explaining the importance of humility in leadership, Covey explained that humility was "one of the characteristics of people at the very top" and noted that such leaders were more teachable, more open in relationships, and show greater respect for others (Flick, 2002, p. 1).

Collins (2001b) noted that Level 5 leaders not only were devoted to the success of their organizations but that they were so committed to that success that they devoted great effort to preparing their successors to effectively assume a leadership role. Possessed of "an almost stoic determination to do whatever needs to be done," Level 5 leaders possess an outcome-based ethical focus with a teleological emphasis on achieving unparalleled success (Collins, 2008, p. 20; Caldwell, et al., 2012). These leaders "look out the window to apportion credit to factors outside themselves when things go well ... (and) they look in the mirror to apportion responsibility, never blaming bad luck when things go poorly" (Collins, 2001a, p. 35). Transformative leaders share the Level 5 leader's commitment to pursue optimal outcomes and are passionately committed to making the personal commitment required to achieve those outcomes (Caldwell, 2012).

\subsection{Covenantal Leadership}

Covenantal leadership views the leader's obligation to stakeholders as rising to the level of a covenantal duty which is owed to both the organization and its members (cf. DePree, 2004, Ch. 1; Caldwell, Bischoff, \& Karri, 2002; Caldwell, et al., 2008). According to this leadership perspective, the leader's role includes teacher, role model, and creator of new meanings in enabling organizations to achieve noble purposes (Pava, 2003; Barnett \& Schubert, 2002). Covenantal leadership "is not an attempt to downplay the human element in organizations, but is an attempt to unleash the great human potential which is often dorminant and silent" (Pava, 2003, p. 26). The leader recognizes that (s)he contributes best to creating new meaning by unleashing the untapped human potential of organizations and their members (Pava, 2003).

The focus of covenantal leadership on creating new insights, creating a learning culture, and seeking truth promotes organizational creativity and continuous improvement (cf. Senge, 2006; Christensen, 2011). The focus on truth emphasizes the applied ethical perspective of covenantal leadership rather than simply the creation of knowledge (Pava, 2003). Covenantal leadership seeks to look past the "illusions" of the conventional thinking which are often the cause of organization dysfunction (Pfeffer, 1998, Ch. 1) and to be committed to discovering truth (Pava, 2003, p. 39-50), to integrating it into one's individual and organizational life (Pava, 2003, p. 51-70), and to developing in others the capacity to become self-sustaining rather than dependent upon the leader for truth (Pava, 2003, p. 153.). Transformative leadership incorporates this obligation to constantly pursue truth and create new meanings for a world striving to understand how to achieve better outcomes (Caldwell, 2012).

\subsection{Servant Leadership}

Servant leadership is a leadership perspective committed to "service to others and recognition that the role of organizations is to create people who can build a better tomorrow" (Parris \& Peachey, 2013, p. 378). In describing servant leadership, Greenleaf (1977, p. 7) called it a philosophy and way of life inherent within the leader's personal identity which begins with the desire to first be a servant of others. Keith (2008) observed that the goal of servant leaders is to change the world and to treat people more humanely. At the same time, servant leaders recognize that they also owe a great duty to a world that needs improving and to organizations that depend upon leaders for success (Greenleaf, 1977; DePree, 2004).

In building relationships with others to serve them and to serve the organization, DePree (2004, p. 11) noted that the leader's obligation was to be "a servant and a debtor" whose first task was "to define reality." Understanding that reality enabled the leader and followers to help the organization to succeed and to enable organization members to achieve their potential (DePree, 2004, Ch. 1; Cameron, 2013). Block (1993) explained that the moral duty of leaders was to honor the stewardship obligation owed to employees--treating them as "owners and partners" rather than as 
commodities or underlings and providing them with the information that they needed to succeed as individuals and as key contributors to the organization.

Consistent with the ethic of care, servant leadership strives to achieve that which is in each individual's best interests (cf. Gilligan, 1993). By honoring duties owed to individuals, servant leadership creates both high trust and organizational citizenship behavior (Pfeffer, 1998) which also enable organizations to achieve their highest potential. Transformative leadership incorporates this moral duty as an obligation that best serves individuals and the organization in optimizing long-term wealth (Caldwell \& Hansen, 2010).

\subsection{Principle-Centered Leadership}

Principle-centered leadership is a leadership perspective based upon the belief that there are universal principles that govern interpersonal, organizational, and societal interaction that apply in leading others (Covey, Merrill, Merrill, 1999). Regardless of country of origin, race, religion, or culture, these universal truths apply to human relationships and define duties owed and the obligations of leadership (Covey, 2004; Lewis, 2001). Consistent with the principles of moral intelligence, leaders have the obligation to do no harm, to create wealth in the present day, and to create wealth for society over the long term (Lennick \& Kiel, 2007).

In their extensive study of leadership effectiveness, Kouzes and Posner (2012) have noted that successful leaders 1) have adopted principles that followers consistently identify as important, and 2) follow a set of common behaviors that affirm that a uniform set of leadership principles govern interpersonal and organizational relationships. The commitment to universal principles conforms to the virtue-based or Aristotelian ethical perspective and requires leaders to seek to understand and apply true principles in honoring their duties and responsibilities (Solomon, 1992). It is by honoring correct principles and "putting first things first" that individuals and organizations are most effective in leading their organizations and honoring the duties it owes to stakeholders (Covey, Merrill \& Merrill, 1999). Transformative leadership seeks to apply universal principles and values in honoring duties to an organization and its stakeholders (Caldwell, et al., 2012).

By incorporating key features of each of these six leadership perspectives, transformative leadership focuses heavily on the moral and ethical duties implicit in each perspective in honoring the stewardship responsibilities of a leader to work for the welfare, growth, and wholeness of stakeholders while optimizing long-term wealth creation (Caldwell, et al., 2012). Figure 1 summarizes the key features of transformative leadership and the contributions from each of the six leadership perspectives.

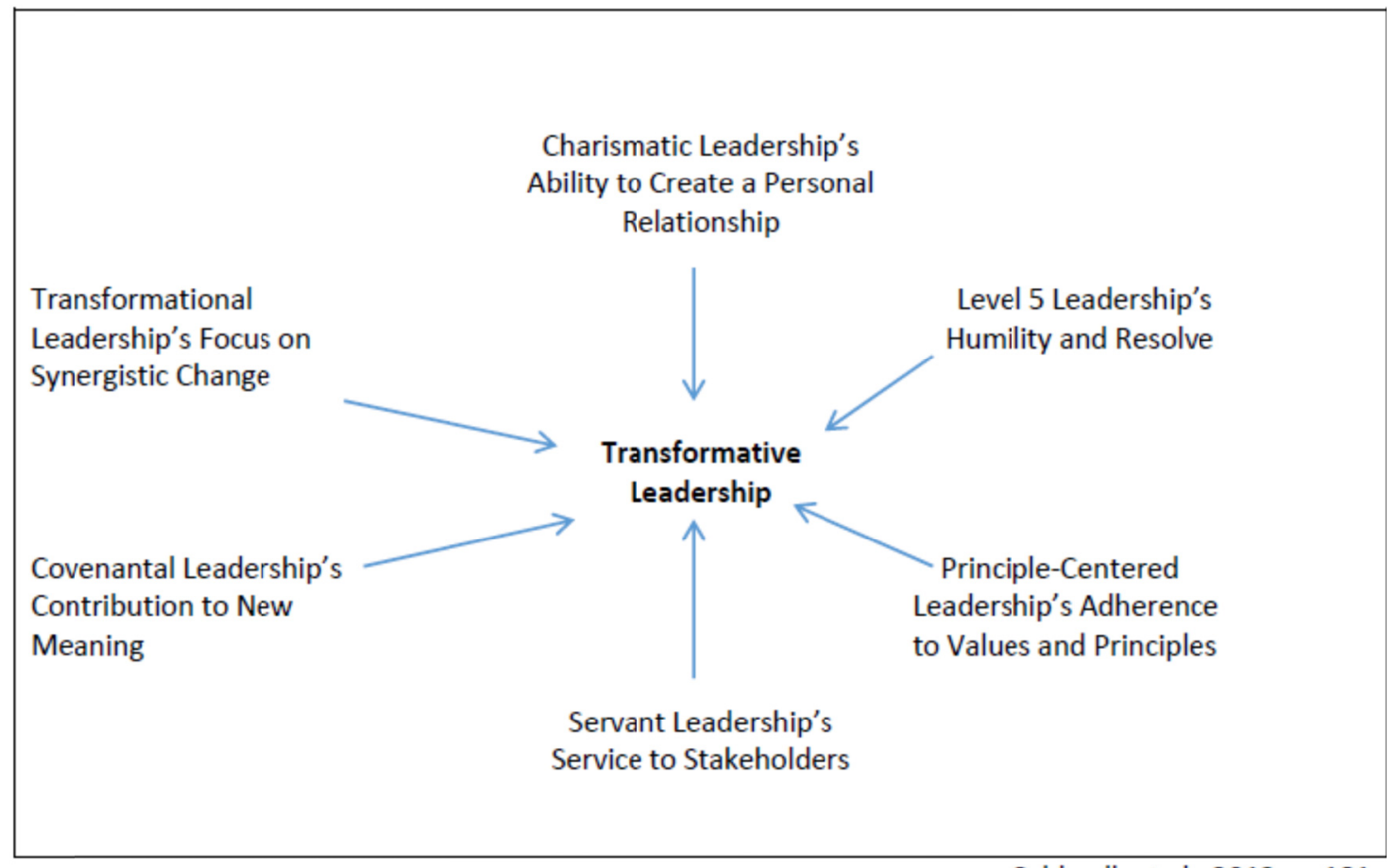

Caldwell, et al., 2012, p. 181

Figure 1. Transformative leadership 


\section{Peter as a Transformative Leader}

In this section we utilize historical, biblical, and scholarly references about Peter to compare his leadership style to the components of transformative leadership. For each of the six leadership perspectives included in transformative leadership we identify how Peter's life parallels with that perspective's leadership approach and ethical duties. In this section we also present twelve propositions about leadership that modern leaders can apply in learning from Peter's leadership style and the elements of transformative leadership.

\subsection{Peter the Charismatic Leader}

In describing the importance of charismatic leadership, Drucker (2006, p.45-49) suggested that a leader's mission or calling is more important than his/her personal style. Charismatic leader's emphasis on the unique nature of the leader's calling (Lussier \& Achua, 2012, p. 363) applies to Peter's role as the head of the new Christian church. The derivation of "charisma" comes from the Greek and means "an undeserved favor" or "gift of grace" commonly associated with spiritual gifts (Kendall \& Strong. 2001). Peter's charge from Christ himself (Matt. 16: 18) legitimized his calling, and his mission enabled him to exercise many enlightened gifts (Kesich, 1992). Jesus' followers had seen him perform miracles repeatedly—he healed the sick (Matt. 8:2-4; John 4:46-54), raised the dead (Luke 7:11-17; John 11), and walked on water (John 6:15-21). Peter did the same (Acts 3:1-11; 9:32-42; Matt. 14:22-33) and because of those miracles, many believed his teachings (John 6:2).

Peter's calling as head of the Church empowered him in speaking to the assembled crowd on the day of Pentecost (Cullman, 1961, p. 33). On that day, Peter demonstrated his ability to touch lives, to make connections, and to inspire followers (cf. Boyatzis \& McKee, 2005) for people were "pricked in their hearts" and decided to reorder their lives and turn to God, the Church gaining some three thousands converts on that one day alone (Acts 2:37-41). This ability to resonate with others, to inspire a shared vision, and to encourage the hearts of others demonstrated Peter's charismatic leadership skills (Kouzes \& Posner, 2012).

Peter's writings also comforted, motivated, and inspired the followers of Christ to achieve "a living hope" and "an inheritance that can never perish, spoil or fade" (RSV 1 Pet. 1: 3-4). Peter's message to the members of the Church strongly parallels the charismatic focus on becoming one's best, typified by his pleas that each member be "born again" and "love one another deeply, from the heart" (RSV 1 Pet. 1:22). Like other charismatic leaders, Peter realized the great value of the message he bore and then devoted himself to helping others to recognize its truth and its ability to transform their lives (cf. Conger \& Kanungo, 1988).

Martin $(1967$, i) described Peter's "ardor" and "powerful nature" as "his leading characteristic by which he effected so much." The charismatic leader's ability to connect with others and to touch their lives on a personal level inspires lives of greatness in the pursuit of a worthy vision and enables great leaders to leave a legacy of profound value (Covey, 2004; Cameron, 2012). This focus on leaving a legacy and honoring a moral obligation to others and to God is often fundamental to the charismatic leader's role (DuBrin, 2013) and was a driving force in Peter's life (Ascough \& Cotton, 2006). Consistent with Peter's role as a charismatic leader, we offer our first three propositions.

\section{$P_{1}$ : Leaders who view their role as a calling and who make the effort to inspire and connect with their colleagues on a personal basis are more effective than leaders who do not share this leadership perspective.}

$P_{2}$ : Leaders who focus their leadership efforts on achieving a noble purpose and leaving a legacy are able to create higher commitment in followers than leaders who do not define their role in those terms.

$P_{3}$ : Leaders who possess and utilize the charismatic gifts valued by followers are able to influence lives, touch hearts, and have an enduring influence on others' lives.

Kouzes and Posner (2012) have identified the vital role of the leader in both inspiring a shared vision and encouraging the hearts of followers. Charismatic leaders often have the ability to touch hearts and to inspire others to achieve great causes (Boyatzis \& McKee, 2005; Kouzes \& Posner, 2003; Kouzes, Posner, \& Bozarth, 2011) and thereby are able to leave a legacy that has a profound impact on the world and on the lives of others (Covey, 2004). This charismatic leadership quality demonstrates the transformative leader's commitment to honoring a great mission or purpose and to inspiring others to pursue a noble calling that, in turn, also blesses others' lives.

\subsection{Peter the Transformational Leader}

As a transformational leader, Peter redefined the emphasis of the Church and emphasized its vital role in changing the lives of its individual members (cf. Koulomzine, 1992). It was Peter who redefined the Church's apostolic 
mission and declared that the gospel and its blessings were to be made available to all of God's children. Under Peter's leadership, the new message of the gospel was to be taught to Gentile as well as Jew. Peter led out in declaring that all who seek to do what is right are eligible for God's blessings, regardless of their lineage (Acts 10: 34-35).

Part of the genius in Peter's leadership is that he engaged the emotional and spiritual longings of his followers, as Burns indicates transformational leaders do (cf. Burns, 1978, p. 4, 20, 36, 200-205). Writing of the transforming revolution such leadership inspires, Burns $(1978$, p. 202) explained that "the birth of the idea or vision that impels the revolution and its adoption by a decisive number of persons are probably the most crucial steps toward transformation." Although Peter's followers may have found it difficult to verify that he had, in fact, seen a heavenly vision, the ideas Peter conveyed resonated with them at deep, emotional levels.

Peter articulated a vision of what might be, of a better life than his followers then had, in pursuit of which their behavior would change - and that is precisely what transformational leaders do (Burns, 1978, p. 4). He connected at deep, transforming emotional levels, as transformational leaders do (Burns, 1978, pp. 202-203). He confronted, openly and energetically, an existing paradigm which needed to be changed. In addressing the transformational impact on change, Burns (1978, p. 202) explained that "a revolution requires conflict, as does all leadership." In explaining the transformational leader's impact, Bass (1990, pp. 257-258) explained that superior leadership "occurs when leaders broaden and elevate the interests of their employees, when they generate awareness and acceptance of the purposes and mission of the group, and when they stir employees to look beyond their own self-interest for the good of the group." Peter's energizing approach to transforming others changed lives and empowered the church (cf. Cameron, 2012).

A major element in Peter's message was the concept of repentance (Acts 3:19), and the very foundation of repentance is change. The Greek word for repentance is metanoia, literally meaning "to change one's mind" (Senge, 2006, p. 13-14) or "to change one's heart" (Burton, 1988). From the Hebrew, the word for repentance was shube (Strong, 2009) or teshubah (Bridger \& Wok, 1976) which meant to return to the light or to turn to God and live (Burton, 1988). It is this focus on personal change and renewal that transformational leaders recognize to be their obligation to individual organization members (Burns, 1978; Bennis \& Nanus, 2007).

As a change agent, Peter devoted his life after Christ's ascension to establishing the new gospel. Peter's writings encouraged followers to endure their trials and uplift and refine their lives (1 Pet. 1, 4). Transformational leadership embraces the pursuit of high standards by both individuals and organizations (Warrick, 2011) and meshes well with Peter's focus on those qualities in the Church and in the individual lives of its followers. Peter's commitment to the welfare of the Church and its followers exemplified transformational leadership's "recognition of duties owed to all stakeholders" as an ethic of duty (cf. Carroll \& Buchholtz, 2012, Ch. 3).

Transformational leadership is a critical element in a world characterized by change, chaos, and conflict (Buchholz \& Rosenthal, 2005). As a transformational leader, Peter sought synergistic solutions that both strengthened the Church and blessed its members (Grant, 1995). He it was, for example, who not only led the change on preaching the gospel to the whole world, and not just to the Jews (thus redefining their "market"), as we have just discussed, but it was he who led the change process which discontinued the three-thousand year old practice of circumcision (Acts 15). Our fourth, fifth and sixth propositions incorporate Peter's perspective in modeling these qualities of transformational leadership in helping organizations to achieve productive change and apply to modern leaders.

$P_{4}$ : Leaders who are perceived as working to achieve both the success of the organization and the growth of their colleagues are able to achieve higher levels of employee commitment than leaders who are perceived as working solely for the benefit of their organization.

$P_{5}$ : Leaders who are perceived as working to achieve both the success of the organization and the growth of their colleagues are able to achieve successful organizational change more rapidly than leaders who are perceived as working solely for the benefit of their organization.

$P_{6:}$ Leaders who confront in good spirit, openly and honestly, organization problems are much more likely to gain organization approval and support than leaders who fail to do so.

Modern leaders who seek to achieve optimal outcomes from their employees are beginning to recognize the practical value of creating organizational cultures and systems that demonstrate this transformational commitment to both the organization and its members (Huselid, 1995; Huselid \& Becker, 1997; Huselid, Jackson, \& Schuler, 1997; Pfeffer, 1998). 


\subsection{Peter the Level 5 Leader}

Peter's combination of personal humility and his fierce commitment to the Church and its mission exemplify features of Level 5 leadership (cf. Collins, 2001a). Peter fit the mold of Level 5 leaders (Collins \& Powell, 2004, p. 710) in combining both a commitment to achieve greatness "combined with the will to make good on it" (Collins \& Powell, 2004, p. 710). Peter's life was wholly devoted to serving the Church and fulfilling its mission (Ehrman, 2006), and he combined a ferocious resolve with a personal humility that took personal responsibility for addressing individual and organizational shortcomings and the need to constantly improve (cf. Collins, 2001).

Peter's personal humility is demonstrated by an incident after a night of fruitless fishing. Peter and his fishing partners were met by Jesus on the shores of the Sea of Galilee After Jesus asked Peter to cast out his net, Peter objected, "Master, we toiled all night and took nothing! But at your word I will let down the nets." Almost immediately, they caught an enormous load of fish which was so heavy that their nets began to break. "They beckoned to their partners in the other boat to come and help them. And they came and filled both the boats, so that they began to sink." Overcome with the difference between Jesus and himself, the humbled Peter fell at Jesus' feet, "saying, 'Depart from me, for I am a sinful man, O Lord." Jesus then promised that the luckless fishermen would become successful missionaries, and "catch men" in the gospel net (RSV Luke 5:1-11).

Though Peter's devotion to his mission and his giving of himself to God exemplified his profound humility, Peter also demonstrated a fierce resolve to serve the Church and to do everything in his power to enable it to grow (Ehrman, 2006, Ch. 6). On the day of Pentecost he did not simply preach a sermon; he preached and then asked his listeners for a commitment - that they be baptized as a result of what he had said (Acts 2:37-38, 41). He wanted converts, not merely interested listeners. When he later preached at the temple, he once again asked his listeners for commitment to repent - to change their behavior (Acts 3:19). When Peter received his great vision directing that the gospel be preached to the Gentiles, he responded immediately. "On the morrow" he left for Caesarea where Cornelius lived, and "the morrow after they entered into Caesarea" (KJV Acts 15:23-24) having walked some thirty miles in less than two days. At the great Council of Jerusalem, in which the early Church debated whether Greeks and other Gentile converts needed circumcision, Peter and the apostles immediately wrote a letter to the church in Antioch so that they might operate by the same standards as the Jerusalem church (Acts 15:1-29). For Peter, there was no time to waste.

Though Peter encouraged Church members and called them "God's special possession" and "a chosen people," (1 Peter 2:9), he nonetheless counseled them to honor that special calling by being obedient in all things. For Peter, this obedience was the key to personal salvation and the purpose of the Church. Peter, like other Level 5 leaders who are concerned about organizational transition (Collins, 2001), included in his letters a charge to the elders of the faith to prepare themselves for future leadership and to honor their duties in keeping the Church strong (1 Peter 5).

Level 5 Leaders possess a leadership style that is typically understated and that is unpretentious, freely giving credit to others for achievements while personally assuming responsibility for poor organizational results (Collins 2001 a \& b). Peter's commitment to the long-term success of the Church, his humble encouragement to its followers to live the gospel, and his personal desire to help members to succeed that are reflected in his letters demonstrate his Level 5 qualities (1 Peter; 2 Peter). Consistent with Peter's example of a humble Level 5 Leader, we present our seventh and eighth propositions.

$P_{7}$ : Leaders who are perceived as humble who freely give credit to others for successes and who assume personal responsibility for organizational failures are more likely to have highly motivated employees and more successful organizations than leaders who lack that humility, fail to give others credit, and blame others for failures.

$P_{8}$ : Leaders who demonstrate humility coupled with a passionate personal commitment to an organization's long-term success are more likely to have highly motivated employees and more successful organizations than leaders who are perceived as lacking humility and being less committed to the organization.

W. Edwards Deming (2000) emphasized that most leaders and organizations fail to understand that 85 to 90 percent of all organizational problems are, in fact, largely due to dysfunctional systems and poor leadership. Level 5 Leaders recognize the need to accept responsibility for dysfunctional organization problems and to "fix the problem" rather than attempting to "fix the blame" on others. 


\subsection{Peter the Covenantal Leader}

In his second epistle, Peter served as the example of a Covenantal Leader in his efforts to teach the Church and to ensure that it stayed on the path of truth (Ehrman, 2006, p. 77). Peter warned about those who would teach falsely (2 Peter 2). Covenantal Leaders (Pava, 2003) serve as exemplars, teachers, role models, and creators of new truth - all roles filled by Peter in guiding the Church throughout his ministry (Kesich, 1992). Peter's role in leading the Church to redefine its scope and to send the Gospel to the entire world is a profound example of the adoption of new learning that epitomizes covenantal leadership (Pava, 2003). Based upon this paradigm shift, the extension of the Church's mission to take its message to Gentiles as well as Jews epitomized the ability of the Church to unleash the human potential which covenantal leadership seeks to achieve by making new knowledge and greater truth available (Pava, 2003).

A second redefining learning moment for the early Church occurred when the Council of Jerusalem decided to eliminate any requirement for circumcision as a precondition for baptism. This new policy reversed a three-thousand year old tradition. Indeed, deSatge (1981, p. 11) calls this event "one of the turning points in human history." In this Council, Peter played a powerful role in the decision-making, and gave the momentum-turning speech which brought closure to the debate and synthesized the triumphant view (Acts 15:1-11).

Peter's letters to the members of the Church attempted to keep them close to the truth, to understand its impact in their lives, and to be able to distinguish between truth and error (2 Peter). As a Covenantal Leader, Peter encouraged the Church to follow the promptings of the Holy Spirit in determining the truth, and it was through this source of light and truth that others developed the ability to understand the impact of the Gospel in their lives (Acts 2).

Covenantal Leaders seek "power with" others, rather than "power over" them (Graham, 2003), while striving to be examples, teachers, and seekers after truth (Pava, 2003). Peter's example of treating Church members with great empowering love typified the Covenantal Leader's devotion to their welfare in the pursuit of truth. Accordingly, we offer our ninth proposition that follows Peter's leadership style.

\section{$P_{9}$ : Leaders who focus on empowering others and who involve them in the process of constant learning and improvement are able to create organizations which are more successful than leaders who fail to adopt this focus.}

Covenantal leadership seeks to honor the pursuit of new meaning, innovation, and the pursuit of truth which are key elements necessary for achieving competitive advantage in today's global marketplace (Christensen, 2011; Pfeffer, 1998).

\subsection{Peter the Servant Leader}

Servant leadership is about treating stakeholders as valued individuals to whom the organization owes a multi-faceted set of moral duties to pursue their welfare, growth, and wholeness (Greenleaf, 1977). Servant leaders strive to identify and meet the needs and priorities of stakeholders and to honor and respect those needs (Block, 1993). At the same time, servant leaders pursue obligations due to the organization itself - believing that the most effective way of creating long-term wealth is by treating others like valued "Yous" or individuals rather than as "Its" or commodities (Covey, 2004; Buber \& Smith, 2000).

Peter valued the individual as Greenleaf said he should - as servant first, then as leader or influencer, ensuring that a person's "highest priority needs" are being met, enabling them to grow and become "healthier, wiser, freer, and more autonomous" and more likely themselves to become servants (Greenleaf, 1970, p. 7). Peter introduced himself as "a servant and apostle of Jesus Christ" (2 Pet. 2:1; italics added), and taught that church members must act "as servants of God" (RSV 1 Pet. 2:16) as well. As the agent of the church Peter promised that those who were, first, God's servants, would, by that service, be saved; through its teachings and ordinances the church would bless and benefit the individual.

In putting service to others over his own self-interest (Block, 1993), Peter eventually was martyred and focused his life on service to the Church, to its membership, and to God (Walsh, 1948). Peter exemplified the idea that "the leader is servant first" (Greenleaf, 1977, p. 7) and spent his life seeking to serve others. Lencioni (2004, p. 71) explained that for the servant leader "to make a real difference is to do so humbly, without regard for recognition, ego, pride, even self-preservation..." Such was Peter's commitment, as is illustrated by the fact that Christ had singled him out on several occasions for positive recognition, had even given him a prominence and notice above that of his fellow apostles (Matt. 16:13-20), and yet Peter never assumed the pre-eminence he might have claimed. Rather, as Jesus had done while still alive (Matt. 9:18-26; Matt. 17:1-8; Matt 26:37) Peter involved James and John in shouldering his burdens and responsibilities (see, e.g., Acts 3:1-11; 4:5-30; 8:14-25; 14:17; 15). 
As a Servant Leader, Peter demonstrated an ethic of care that reflected his commitment to the relationships (Cameron, 2011) that he had with the Church and its members. We see that caring in the healings he performed (Acts $3: 1-11 ; 9: 32: 42$ ), and in the welfare program the church established (Acts 2:44-46; 4:31-37). Peter's personalized identification of others in his letters and his desire to serve and protect them comes across in the poignant pleas of his letters. This commitment to serving other organization members and to striving to achieve their welfare is part of the sacred duty of modern leaders (Gullett, et al., 2009), and Peter's example modeled that commitment powerfully. Consistent with Peter's example as a great servant leader, we present our tenth and eleventh propositions.

$P_{10}$ : Leaders who demonstrate that they care deeply about the individual success of their employees are more likely to be perceived as more trustworthy than leaders who do not demonstrate this quality.

$P_{11}$ : Leaders who demonstrate that they care deeply about the individual success of their employees find that their employees are more committed to their organization's success than other leaders who do not demonstrate this quality.

Servant leadership that treats employees as valued partners has been successfully applied in a growing number of organizations and empirical evidence suggests that leaders who adopt this leadership approach can create cultures of high trust and high performance (Pfeffer, 1998; Paine, 2003; Cameron, 2003).

\subsection{Peter the Principle-Centered Leader}

Just as the Principle-Centered Leader seeks to follow a set of universal truths, in governing oneself and others (Covey, 1991), Peter embraced the Gospel of Jesus Christ and its teachings and principles in leading the early Church (Perkins, 2000). Founded in virtue ethics, principle-centered leaders identify guidelines, virtues, and character traits essential to living an honorable life (Solomon, 1992). This commitment to virtuousness and to true principles has been described as a key element of responsible leadership and a source of improved organizational performance (Cameron, 2011). Peter's life and mission exemplified his virtuous commitment to the teachings that he espoused (Ascough \& Cotton, 2006).

Principle-Centered Leaders also emphasize the importance of creating high trust with stakeholders (Bandsuch, Pate, \& Thies, 2008), based upon the leader's integrity in living and modeling those principles (Maxwell, 2004, p. 42). The ethical obligation of the principle-centered leader is to learn and apply correct principles and to teach them to others. Leaders who operate according to universal principles have a moral obligation to carefully examine the impact of their actions, weigh the costs and benefits, and clarify to others the purposes and rationale behind their actions (Hosmer, 2007: Ch. 1). Peter's sermons to potential converts and his letters to the members of the new Christian Church reflect his commitment to the principles that he taught and the importance of those principles in the lives of his followers (Acts 2-3, 10, 15; 1 Peter, 2 Peter).

Kouzes and Posner (2004, p. 11) remind us that "(l)eaders understand how important it is to be clear about the values and motivations that drive them." Just as Peter continually clarified the Gospel's principles and requirements to the early members of the Church, modern day leaders who are principle-centered must also articulate clear guidelines for their employees. Incorporating Peter as an example of principle-centered leadership, we propose our tweltfh proposition.

$P_{12}$ : Leaders who articulate the principles that guide them and who communicate those principles to others create higher trust and commitment than leaders who do not communicate in that way.

Hosmer (2007, Ch. 1) identifies the moral and ethical obligation of leaders to clarify what they believe; how their decisions are made; and the impacts of those decisions on stakeholders financially, legally, and ethically. Hosmer's model is an effective resource for the modern leader seeking to build trust and employee commitment and meshes well with Peter's role as a Principle-Centered Leader.

\section{Contributions of Our Paper}

Understanding the importance of the leadership style of Peter can be personally inspiring from a religious perspective but also has practical applications. The following are five contributions that our paper makes to the academic and practitioner literature.

1) We affirm the importance of Peter as a great leader of the early Christian church and provide examples of his inspiring leadership. Peter's role as a leader made a significant contribution in providing clear direction for the expansion of the early church's missionary program in taking the message of Christ "to all the world" (Mark 16:15). Peter's loving counsel (1 Peter, 2 Peter) and his call to repentance (Acts 2:38) reflect his commitment to the welfare, 
growth, and wholeness of the members of the new gospel, and Peter's personal example after Christ's ascension demonstrated his commitment to the church and to its mission (Koulomzine, 1992; Ascough \& Cotton, 2006).

2) We demonstrate that Peter's leadership style is typical of that of the transformative leader, a leadership style that imposes high moral standards and integrates ethically-related elements of six highly regarded leadership perspectives. The importance of the transformative leader has been affirmed by many scholars (Burns, 1978; Bennis \& Nanus, 2007). In this paper we compare Peter's leadership style with the transformative leadership model explained in detail by Caldwell and colleagues (2012) and emphasize the moral and ethical nature of transformative leadership in integrating duty-based elements of six highly-regarded leadership perspectives (cf. Caldwell, 2012).

3) We provide practical insights for the modern leader and for scholars in enabling them to understand the value of following Peter's leadership examples and provide twelve propositions for improving leadership effectiveness that apply to the modern leader. Practical insights about the application of leadership continue to generate disagreement, despite the fact that hundreds of books and thousands of articles have been written about the topic (Kouzes \& Posner, 2012). Although the importance of building high commitment and trust are fundamental to the success of the modern organization, leaders nonetheless continue to act with a disregard for followers and for moral duties owed (Pfeffer, 1998; Covey, 2004) - despite the evidence that successful organizations are dependent upon leaders who recognize the need to achieve both moral and economic outcomes to be effective (Cameron, 2011; Paine, 2003; Senge, 2006).

4) We join with those who have emphasized the importance of virtuous leadership as a valued leadership model that holds leaders accountable to the highest standards of moral leadership. Leaders have an obligation to be responsible and virtuous (Cameron, 2011). Peter's example and the key elements of transformative leadership (Caldwell, et al., 2012) affirm the need for today's leaders to rise above old leadership models and to integrate a highly ethical, conscience-based, and virtuous approach to dealing with stakeholders in governing organizations (Covey, 2004; Covey, Merrill \& Merrill, 1999). Creating high trust and commitment are dependent upon virtuous leadership (Cameron, 2011; Senge, 2006) to enable people and organizations to achieve "the best of the human condition or the highest aspirations human beings hold for themselves" and their organizations (Cameron and Winn, 2012, p. 231).

5) We demonstrate the value of learning from the past--even the ancient past -- to illustrate the durability of principles in the relationship between leaders and followers and to affirm the importance of moral duties owed in the process of governance. Although the challenge of effective governance has been a fundamental issue facing organizations for millennia (Manville \& Ober, 2003), leaders struggle to retain trust and followership (Caldwell, Hayes, \& Long, 2010). Bass and Steidlmeier (1999, p. 182) have suggested that the ethics of leadership requires understanding (1) the moral character demonstrated by the leader; (2) the ethical legitimacy of the embedded principles and processes of the leader's vision and the program which followers are expected to accept; and (3) the morality of the actions and choices in which leaders and followers are engaged. The leadership style of past leaders can affirm the importance of understanding the importance of these ethical and moral insights and the true principles which they affirm in governing ourselves (Covey, 1991; Covey, Merrill \& Merrill, 2004; Cameron, 2012; Kouzes \& Posner, 2012).

\section{Conclusion}

In his important new book, Jim Loehr (2012) reminds us that the pursuit of great objectives requires a fundamental understanding of both normative and instrumental outcomes that address both duties owed to society and the relationships that we create with others. Ultimately, successful leadership recognizes that we must balance our lives in achieving inner peace, personal achievement, and meaningful outcomes (Covey, Merrill \& Merrill, 1999; Covey, 2004; Quinn, 2005).

This important need to follow a compass that is based upon enduring truths was a fundamental basis for Peter's life, and he devoted his life after Christ's ascension to living in harmony with what he believed to be eternal truths (Ascough \& Cotton, 2006). Peter's leadership style integrated a commitment to principles, a focus on results, a love for others, and congruence with his inner conscience (cf. Covey, 2004; Quinn, 2005). As modern practitioners and scholars study the life of Peter and seek to learn from his example, they have the opportunity to affirm Peter's transformative commitment to creating a better world, despite the obstacles facing every leader in a world marked by constant change, uncertainty, and turbulence (Pearson, 2012). Despite the challenges facing modern leaders and organizations, following Peter's example can enable today's leaders to achieve "moments of greatness" that endure and that add value to their organizations and the stakeholders that they serve (Quinn, 2005, p. 74). 


\section{References}

Anding, J. M. (2005). An interview with Robert E. Quinn: Entering the fundamental state of leadership: Reflections on the path to transformational teaching. Academy of Management Learning \& Education, 4(4), 487-495. http://dx.doi.org/10.5465/AMLE.2005.19086790

Ascough, R. S., \& Cotton, C. A. (2006). Passionate Visionary: Leadership Lessons from the Apostle Paul. Peabody, MA: Hendrickson Publishers, Inc.

Avolio, B., Waldman, D., \& Yammarino, F. (1991). Leading in the 1990's: The Four I's of Transformational Leadership. Journal of European Industrial Training, 15(4), 9-16.

Bandsuch, M., Pate, L., \& Thies, J. (2008). Rebuilding Stakeholder Trust in Business: An Examination of Principle-Centered Leadership and Organizational Transparency in Corporate Governance. Business and Society Review, 113(1), 127. http://dx.doi.org/10.1111/j.1467-8594.2008.00315.x

Barnett, T., \& Schubert, E. (2002). Perceptions of the ethical work climate and covenantal relationships. Journal of Business Ethics, 36(3), 279-290. http://dx.doi.org/10.1023/A:1014042613106

Bass, B.M. (1990). From Transactional to Transformational Leadership: Learning to Share the Vision. Organizational Dynamics, 18(3), pp. 19-31, Cited in J. Timothy McMahon, Leadership Classics (2010, pp. 256-269). Long Grove, Ill.: Waveland Press.

Bass, B. M., \& Steidlemeier, P. (1999). Ethics, Character, and Authentic Transformational Leadership Behavior. Leadership Quarterly, 10(2), 181-217. http://dx.doi.org/10.1016/S1048-9843(99)00016-8

Bennis, W., \& Nanus, B. (2007). Leaders: Strategies for Taking Charge (2nd ed.). New York: Harper-Collins.

Block, P. (1993). Stewardship: Choosing Service Over Self-Interest. New York: Berrett-Koehler.

Boyatzi, R. .E., \& McKee, A. (2005). Resonant Leadership: Renewing Yourself and Connecting with Others Through Mindfulness, Hope, and Compassion. Boston, MA: Harvard Business School Press.

Bridger. D., \& Wolk, S. (1976). The New Jewish Encyclopedia. New York: Behrman House.

Brown, M. E., \& Trevino, L. K. (2006). Ethical Leadership: A Review and Future Directions. Leadership Quarterly, 17(6), 595-616. http://dx.doi.org/10.1016/j.leaqua.2006.10.004

Buchholz, R. A., \& Rosenthal, S. B. (2005). Toward a contemporary conceptual framework for stakeholder theory. Journal of Business Ethics, 58(1-3), 137-148. http://dx.doi.org/10.1007/s10551-005-1393-8

Buber, M., \& Smith, R. G. (2000). I and Thou. New York: Scribner.

Burns, J. (1978). Leadership. New York: Harper Row.

Burton, T. M. (1988, August). The Meaning of Repentance. Ensign Magazine, pp. 6-9.

Caldwell, C. (2012). Moral Leadership: A Transformative Model for Tomorrow's Leaders. New York: Business Expert Press. http://dx.doi.org/10.4128/9781606492543

Caldwell, C., Bischoff, S. J., \& Karri, R. (2002). The Four Umpires: A Paradigm for Ethical Leadership. Journal of Business Ethics, 36(1/2), 153-163. http://dx.doi.org/10.1023/A:1014230002724

Caldwell, C., Dixon, R. D., Floyd, L. A., Chaudoin, J., Post, J., \& Cheokas, G. (2012). Transformative Leadership: Achieving Unparalleled Excellence. Journal of Business Ethics, 109(2), 175-187. http://dx.doi.org/10.1007/s10551-011-1116-2

Caldwell, C., Hayes, L. A., Karri, R., \& Bernal, P. (2008). Ethical Stewardship: Implications for Leadership and Trust. Journal of Business Ethics, 78(1-2), 153-164. http://dx.doi.org/10.1007/s10551-006-9320-1

Caldwell, C., Hayes, L., \& Long, D. (2010). Leadership, Trustworthiness, and Ethical Stewardship. Journal of Business Ethics, 96(4), 497-512. http://dx.doi.org/10.1007/s10551-010-0489-y

Caliguire, J. (2003). Leadership Secrets of Saint Paul. Colorado Springs, CO.

Cameron, K. S. (2003). Ethics, Virtuousness, and Constant Change. In N. M. Tichy and A. R. McGill (Eds.), The Ethical Challenge: How to Lead with Unyielding Integrity (pp. 185-194). San Francisco, CA: Jossey-Bass.

Cameron, K. S. (2011). Responsible Leadership as Virtuous Leadership. Journal of Business Ethics, 98(1), 25-35. http://dx.doi.org/10.1007/s10551-011-1023-6 
Cameron., K. S. (2012). Positive Leadership: Strategies for Extraordinary Performance. San Francisco, CA: Berrett-Kohler.

Cameron, K. S. (2013). Practicing Positive Leadership: Tools and Techniques that Create Extraordinary Results. San Francisco, CA: Berrett-Kohler.

Cameron, K. S., \& Spreitzer, G. M. (Eds.) (2012). The Oxford Handbook of Positive Organizational Scholarship. Oxford: Oxford University Press.

Cameron, K.S., \& Winn, B. (2012). Virtuousness in organizations. In K. S. Cameron and G.M. Spretizer (Eds.), The Oxford handbook of positive organizational scholarship (pp. 231-243). Oxford: Oxford University Press.

Carroll, A B., \& Buchholtz, A. K. (2011). Business \& Society: Ethics, Sustainability, and Stakeholder Management (8th ed.). Mason, OH: Cengage Learning.

Christensen, C. M. (2011). The Innovator's Dilemma: The Revolutionary Book that Will Change the Way That You Do Business. New York: Harper.

Ciulla, J. B., Price, T. L., \& Murphy, S. E. (2005). The quest for moral leaders: Essays on leadership ethics. Northampton, MA: Edward Elgar. http://dx.doi.org/10.4337/9781845427993

Clinton, J. R. (2006). Philemon - A Study in Leadership Style. Altadena, CA: Barnabas Publishers.

Collins, J. (2001a). Good to great: Why some companies make the leap... and others don't. New York: HarperCollins.

Collins, J. (2001b). Level 5 Leadership: The Triumph of Humility and Fierce Resolve. Harvard Business Review, 79(1), 66-76.

Collins, J. (2008). Celebrity leadership. Leadership Excellence, 25(1), 20.

Collins, J., \& Powell, S. (2004). SPOTLIGHT: The Characteristics of Level 5 Leadership. Management Decision, 42(5-6), 709-716.

Conger, J. A., \& Kanungo, R. N. (1988). Behavioral Dimensions of Charismatic Leadership in Charismatic Leadership. San Francisco, CA: Jossey-Boss., p. 78-97.

Conger, J. A., \& Kanungo, R. N. (1998). Charismatic Leadership in Organizations. Thousand Oaks, CA: Sage Publications.

Covey, S. R. (1989). The 7 Habits of Highly Effective People. New York: Simon and Schuster.

Covey, S. R. (1991). Principle-Centered Leadership. New York: Summit Books.

Covey, S. R. (2004). The 8th habit: From effectiveness to greatness. New York: Free Press.

Covey, S. R., Merrill, A. R., \& Merrill, R. R. (1999). First Things First: To Live, to Love, to Learn, and to Leave a Legacy. New York: Simon \& Schuster.

Cullman, O. (1961). Peter: Disciple, Apostle, Martyr. Cleveland, OH: Meridian. New York: Free Press.

de Satge, John. (1981). Peter and the Single Church. London: SPCK.

Deming, W. E. (2000). Out of the Crisis. Cambridge, MA: MIT Press.

DePree, M. (2004). Leadership is an art. New York: Doubleday.

Drucker, P. F. (2006). Managing the Nonprofit Organization: Principles and Practices. New York: Harper.

DuBrin, A.. J. (2013). Leadership: Research Findings, Practice, and Skills. Mason, OH: South-Western.

Ehrman B.D. (2006). Peter, Paul, and Mary Magdalene. Oxford: Oxford University Press.

Flick, H. (2002). Recipe for Humble Pie Provided. [MSU Memo] 14 June 2002. Retrieved from http://msuinfo.ur.msstate.edu/msu_memo/1998/06-15-98/humility.htm

Gilligan, C. (1993). In a different voice: Psychological theory and women's development. Boston, MA: Harvard Business School Press.

Graham, P. (2003). Mary Parker Follett prophet of management. Frederick, MD: Beard Books.

Grant, M. (1995). Saint Peter. New York: Scribner. 
Greenleaf, R. K. (1970). The Servant as Leader. Indianapolis, Ind.: Robert K. Greenleaf Center for Servant-Leadership.

Greenleaf, R. K. (1977). Servant leadership: A journey into the nature of legitimate power and greatness. New York: Paulist Press.

Gullet, J., Canuto-Carranco, M., Brister, M., Turner, S., \& Caldwell, C. (2009). The Buyer-Supplier Relationship: An Integrative Model of Ethics and Trust. Journal of Business Ethics, 90(3), 329-341. http://dx.doi.org/10.1007/s10551-010-0430-4

Hayibor. S., Agle, B., Sears, G., Sonnenfeld, J., \& Ward, A. (2011). Value Congruence and Charismatic Leadership in CEO-Top Manager Relationships: An Empirical Investigation. Journal of Business Ethics, 102(2), 237-254. http://dx.doi.org/10.1007/s10551-011-0808-y

Hernandez, M., (2012). Toward an Understanding of the Psychology of Stewardship. Academy of Management Review, 37(2), 172-193. http://dx.doi.org/10.5465/amr.2010.0363

Hosmer, L. T. (2007). The ethics of management (6th ed.). New York: McGraw-Hill.

Huselid, M. A. (1995). The Impact of Human Resource Management Practices on Turnover, Productivity, and Corporate Financial Performance. Academy of Management Journal, 38(3), 635-672. http://dx.doi.org/10.2307/256741

Huselid, M. A., \& Becker, B. E. (1997). The impact of high performance work systems, implementation effectiveness, and alignment with strategy on shareholder wealth. Columbia, United States, Columbia: Academy of Management.

Huselid, M. A., Jackson. S. E., \& Schuler, R. S. (1997). Technical and Strategic Human Resource Management Effectiveness as Determinants of Firm Performance. Academy of Management Journal, 40(1), 171-188. http://dx.doi.org/10.2307/257025

Keith, K. (2008). The case for servant leadership. Westfield, IN: Greenleaf Center for Servant Leadership.

Kendall, R. P., \& Strong, J. (2001). The New Strong's Expanded Dictionary of Bible Words. New York: Thomas Nelson.

Kennedy, J. F. (2006). Profiles in Courage. New York, Harper Perennial Modern Classics.

Kesich, V. (1992). Peter's Primacy in the New Testament and the Early Tradition. In J. Meyendorff (Ed.), The Primacy of Peter: Essays in Ecclesiology and the Early Church (3rd ed., pp.35-66.). Crestwood, NY: St. Vladimir's Seminary Press.

King, R. A. (2012). A Biography of Saint Simon Peter the Apostle: From Fisherman to Martyr. Casa Grande. AZ: King \& Associates.

Koulomzine, N. (1992). Peter's Place in the Primitive Church. In J. Meyendorff (Ed.), The Primacy of Peter: Essays in Ecclesiology and the Early Church (3rd ed., pp. 11-34). Crestwood, NY: St. Vladimir's Seminary Press.

Kouzes, J. M., \& Posner, B. Z. (2003). Encouraging the Heart: A Leader's Guide to Rewarding and Recognizing Others. San Francisco, CA: Jossey-Bass.

Kouzes, J. M., \& Posner, B. Z. (2004). The Five Practices of Exemplary Leadership in Christian Reflections on The Leadership Challenge. San Francisco, CA: Jossey-Bass, pp. 1-38.

Kouzes, J. M., \& Posner, B. Z. (2012). The Leadership Challenge; How to Make Extraordinary Things Happen in Organizations (5th ed.). San Francisco, CA: Jossey-Bass.

Kouzes, J. M., Posner, B. Z., \& Bozarth, J. (2011). Strengthening Credibility: A Leader's Workbook. San Francisco, CA: Jossey-Bass.

Lencioni, P. (2004). Reflections on Challenge the Process. In J. M. Kouzes and B. Z Posner (Eds.), Christian Reflections on The Leadership Challenge (pp. 71-81). San Francisco, CA: Jossey-Bass.

Lennick, D., \& Kiel, F. (2007). Moral intelligence: Enhancing business performance \& leadership success. Upper Saddle River, NJ: Wharton School Publishing.

Lewis, C.S. (2001). Mere Christianity. New York: HarperCollins.

Loehr, J. (2012). The Only Way to Win: How Building Character Drives Higher Achievement and Greater Fulfillment in Business and Life. New York: Hyperion. 
Lussier, R.N., \& Achua, C.F. (2012). Leadership: Theory, application, \& skill development. South Mason. OH: South-Western.

Lussier, R.N., \& Achua, C.F. (2013). Leadership Theory, Application, \& Skill Development. Mason, OH: Thomson Higher Education.

Manville, B., \& Ober, J. (2003). A company of citizens: What the world's first democracy teaches leaders about creating great organizations. Boston, MA: Harvard Business School Publishing.

Martin, H. (1967). Simon Peter. London: The Banner of Truth Trust.

Maxwell, J. C. (2004). Reflections on Model the Way. In J. M. Kouzes and B. Z Posner (Eds.), Christian Reflections on the Leadership Challenge (p. 41-52). San Francisco, CA: Jossey-Bass.

Paine, L. S. (2003). Value shift: Why companies must merge social and financial imperatives to achieve superior performance. New York: McGraw-Hill.

Parris, D. L, \& Peachey, J. W. (2013). A systematic literature review of servant leadership: Theory in organizational contexts. Journal of business ethics, 113(3), 377-393. http://dx.doi.org/10.1007/s10551-012-1322-6

Pava, M. L. (2003). Leading with meaning: Using covenantal leadership to build a better organization. New York: Palgrave Macmillan.

Pearson, C. S. (2012). The Transforming Leader: New Approaches for the Twenty-first Century. New York: Berrett-Koehler Publishers.

Perkins, P. (2000). Peter: Apostle for the Whole Church. Minneapolis, MN: Fortress Press.

Pfeffer, J. (1998). The Human Equation: Building Profits by Putting People First. Boston, MA: Harvard Business School Press.

Phillips, D. T. (1993). Lincoln on Leadership: Executive Strategies for Tough Times. New York: Warner Books.

Quinn, R. E. (2005). Moments of Greatness. Harvard Business Review, 83 (7-8), 74-83.

Rasnake, E. \& Shepher, R. (2001). Life Principles from the Old Testament: Leaders Guide. Chatanooga, TN: AMG Publishers.

Senge, P. (2006). The fifth discipline: The art and practice of the learning organization. New York: Doubleday.

Solomon, R. C. (1992). Ethics and excellence: Cooperation and integrity in business. New York: Oxford University Press.

Strong, J. (2009). Strong's Exhaustive Concordance of the Bible. Peabody, MA: Hendrickson Publishers.

Thiede, C. P. (1986). Simon Peter: From Galilee to Rome. Exeter, England: Paternoster Press.

Walsh, W. T. (1948). Saint Peter The Apostle. New York: The Macmillan Company.

Warrick, D. D. (2011). The Urgent Need for Skilled Transformational Leaders: Integrating Transformational Leadership and Organization Development. Journal of Leadership, Accountability and Ethics, 8(5), 11-26.

Youssef, M. (2013). The Leadership Style of Jesus: How to Make a Lasting Impact. Sarasota, FL: Harvest House Publishers. 